\title{
MEASUREMENT DESIGN FOR SME'S BUSINESS PERFORMANCE IN BANGKOK
}

\author{
Supattra Pranee
}

Suan Sunandha Rajabhat University, Bangkok, Thailand

This research study is dedicated to measurement design for SMEs business performance in Bangkok. The objective was to create some sort of a metrics for assessing the performance of SMEs in Bangkok. This is a documentary research since it is using secondary data. Analysis and synthesis methods were used in relation to the obtained information so that to come up with a measurement of business performance for SMEs operating in the city of Bangkok.

Our research results found that the innovation management model of SMEs is usually composed of 3 structural elements: 1. Finance, 2. Customers, and 3. Stakeholders. Further,

1. The structural element of Finance is composed of the following indicators: 1). Growth revealed through increased sales, market share, profit growth; 2) Return, namely 2.1) Return on assets, 2.2) Return rate for shareholders, 2.3). Average return on sale, and 3) Cash flow as 3.1) Net cash flow, 3.2) Cash flow from sales, 3.3) Inventory turnover.

2. The structural element called Customer is measured through the following indicators: 2.1) Satisfaction of customers with product delivery meeting Terms and Conditions of agreements, 2.2) Satisfaction of customers with a company as compared to competitors, 2.3) Satisfaction of customers with competitive position this company has already received.

3.The structural element of Stakeholder is measured through the following indicators and their parameters: 3.1) Employees and how they are satisfied with returns, 3.2) Return on investment and returns for shareholders when compared to the previous 3-year period, 3.3) Service quality in its dynamics, 3.4) Number of third parties (distributors) involved and how it increases with every new year, 3.5) Activities' arrangements as responding to society's or community's needs, including company's environmental responsibility.

Keywords: measurement; SMEs; business performance.

\section{Introduction}

Small and medium enterprises (SME) together form a huge share of businesses in Thailand. Most of these entrepreneurs do their businesses as natural persons. Some of these natural persons form groups of persons or partnerships (not corporate or limited partnership) to sale their products and services together. All these forms in Thailand are usually specified according to the regulation of the Ministry of Industry depending on the amount of labor involved and the value of assets in the property of small and medium enterprises.

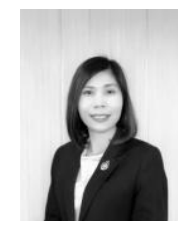

Supattra Pranee

Master of Education (Quality Management), Suan Sunandha Rajabhat University, Bangkok, Thailand Lecturer, College of Innovation and Management, Suan Sunandha Rajabhat University, Bangkok, Thailand Research interests: Business Administration, Management 


\section{MEASUREMENT DESIGN FOR SME'S}

The share of SMEs in the Gross Domestic Product (GDP) of the country, as of 2015, demonstrated the growth of about $5.3 \%$, thus reaching the level of $41.1 \%$. Especially high rates of growth have been observed in tourism, construction, retail and transportation and also logistics businesses.

GDP of the SME sector alone in the year 2015 reached the value of 5,559,534 mln baht, this is $41.1 \%$ of the GDP overall. This share is again on the rise since 2009 (at that year it was no higher than $40 \%$ ), and the statistics shows that the expansion of small businesses is $0.4 \%$ larger than the expansion of mid-sized companies. GDP share of small businesses alone back in 2015 was 3,938,842 mln baht, this was $5.7 \%$ higher than the same indicator one year before that.

The GDP share of mid-sized enterprises back in 2015 was 1,620,692 mln baht, this is $4.3 \%$ growth from the previous year. Rapid growth rate of the SME sector is especially observable in the service sector, in tourism in the first place.

From all of the numbers above we can clearly see that both MEs and SEs are important for economic dynamics and the overall development of Thai economy. For this very reason, the researcher was interested in business performance measurement to be designed specifically for the SMEs of Bangkok, the capital of Thailand.

\section{Literature review}

Performance evaluation is important for organizations of all sizes because it helps improve both efficiency and effectiveness of organizations. Kennerly and Neely (2002) provided the definition of what performance evaluation means. In their opinion, the process of performance evaluation in terms of both efficiency and effectiveness of running business concerns not only financial measurements but also non-financial ones, the latter being designed for the manager to get important information on the current situation of business and its future development trends.

Performance evaluation of businesses has once started from the study of famous (Garrigos-Simon \& Marques, 2004) who, inter alia, offered the following 10 key indicators:

1) Average economic profitability (Return on assets);

2) Average financial profitability (return on investment);

3) Average sales' profitability (return on sales);

4) Average sales growth;

5) Increased market share;

6) Wealth creation (market value ratio/ the book value of a company);

7) Customer satisfaction (the average customer satisfaction index);

8) Employees' satisfaction;

9) Overall competitive position;

10) The succession rate of launching a new product.

Tsai \& Lin (2007), on the opposite, used only two performance evaluation indicators which are: goal achievement and satisfaction with participation. 
Salaheldin (2009) expanded the list of performance evaluation indicators to include 15 of them as follows:

1) Cost reduction;

2) Waste reduction;

3) Product quality improvement;

4) Improving flexibility ;

5) Improving delivery efficiency;

6) Income growth;

7) Net profit;

8) Return on equity ratio;

9) Return on asset;

10) Investment in $R \& D$;

11) Capacity development;

12) Competitiveness;

13) New product development;

14) Market development;

15) Marketing plan.

Hung et al., (2010) developed own performance evaluation method with 6 indicators only:

1) Competitive advantage,

2) Market share,

3) Profit,

4) Production cost,

5) Income,

6) Customer satisfaction.

Chan \& Sim (2011) also had 6 indicators only, however, quite different from those above:

1) Cost reduction,

2) Reduction of operating time,

3) Sales volume,

4) Inventory turnover,

5) Responding to customer requirements,

6) Reject / return rate of a product.

Agus \& Hajinoor (2012) managed to minimize performance evaluation of business to 4 indicators only:

1) Profitability,

2) Market share, 


\section{MEASUREMENT DESIGN FOR SME'S}

3) Return on sales,

4) Return on assets.

Yang \& Liu (2012) went even further and limited performance evaluation of businesses to 3 indicators only:

1) The ability to respond better to both known and unpredictable changes;

2) The ability to supply products and services that would meet the requirements and the demands of customers;

3) Competitiveness and profitability in their dynamics.

Green \& Inman (2014) expanded the list of performance evaluation measures to 7 indicators:

1) Average rate of investments;

2) Operating profit;

3) Profit growth;

4) Return on sales;

5) Market share growth;

6) Increased sales volume in its continuity;

7) Growth of sales.

\section{Methodology}

This study is a documentary research based on secondary data obtained from other research studies in the related field. The methods of data analysis and data synthesis were actively applied to get the components and measure SME business performance in Bangkok, Thailand.

\section{Results and conclusions}

Our research result has found that the management model of SME is composed of 3 structural units which can be called: 1. Finance, 2. Customers and 3. Stakeholders. On a deeper, all three can be further divided as follows:

Finance element consists of the following indicators: 1). Growth seen as increased sales, market share and profit growth; 2) Parameter of return which covers 2.1) Return on assets, 2.2) Return for shareholders, 2.3). Average return on sales and finally 3) Cash flow which is 3.1) Net cash flow, 3.2) Cash flow from sales, 3.3) Inventory turnover.

The structural element Customer consists of the following parameters: 2.1) Satisfaction of customers with product delivery meeting all Terms and Conditions of the agreement, 2.2) Satisfaction of customers with this particular company as compared to the closest 
competitors, 2.3) Satisfaction of customers with a competitive position this particular company got at the moment.

The structural element titled Stakeholder covers the following indicators: 3.1) Employees who are satisfied with returns; 3.2) Return on investment and return for shareholders when compares to the previous 3-year period; 3.3) Service quality in the process of its development; 3.4) Amount of third party/Distributors increase every year 3.5) Activity arrangements responding to society's or community's needs, including those related to companies' social and environmental responsibility.

Table 1. SMEs' business performance measurement

(compiled by the author)

\begin{tabular}{|c|c|c|}
\hline Structure & Indicators & Measure \\
\hline \multirow{9}{*}{ Finance } & \multirow[t]{3}{*}{ 1.Growth } & 1.Increased sales \\
\hline & & 2.Increased market share \\
\hline & & 3.Growth of profits \\
\hline & \multirow[t]{3}{*}{ 2.Return } & 4. Return on assets \\
\hline & & 5. Return on equity \\
\hline & & 6. Average return on sales \\
\hline & \multirow[t]{3}{*}{ 3.Cash flow } & 7. Net cash flow \\
\hline & & 8. Cash flow from sales \\
\hline & & 9. Inventory turnover \\
\hline \multirow[t]{3}{*}{ Customer } & \multirow[t]{3}{*}{ 4.Customer } & $\begin{array}{l}\text { 10. Satisfaction of customers with product delivery } \\
\text { and meeting Terms and Conditions of agreements }\end{array}$ \\
\hline & & $\begin{array}{l}\text { 11. Satisfaction of customers with this company as } \\
\text { compared to its competitor }\end{array}$ \\
\hline & & $\begin{array}{l}\text { 12. Satisfaction of customers with the competitive } \\
\text { position of this company }\end{array}$ \\
\hline \multirow[t]{5}{*}{ Stakeholder } & \multirow[t]{5}{*}{ 5. Stakeholder } & 13. Employees are satisfied with returns \\
\hline & & $\begin{array}{l}\text { 14. Return on investments and return for } \\
\text { shareholders as compared to the previous 3-year } \\
\text { period }\end{array}$ \\
\hline & & 15. Service quality in its development \\
\hline & & $\begin{array}{l}\text { 16. The number of third parties (distributors) in its } \\
\text { increase/decrease each year }\end{array}$ \\
\hline & & $\begin{array}{l}\text { 17. Activities and projects responding to social and } \\
\text { /or community needs, including those directly } \\
\text { related to social and environmental responsibility }\end{array}$ \\
\hline
\end{tabular}

The research results on the suitable performance measures for SMEs in Bangkok were thus structured into 3 larger units, 5 indicators and 17 measures. This structuring took into account the research results and achievements of Agus \& Hajinoor (2012), Chan \& Sim, (2011), Hung et al. (2010), Kennerly \& Neely (2002), Garrigos-Simon \& Marques (2004), Salaheldin (2009), Tsai \& Lin (2007), Chan \& Sim (2011), Tanapol (2015). 


\section{MEASUREMENT DESIGN FOR SME'S}

\section{References:}

Agus \& Hajinoor (2012). Lean production supply chain management as the driver towards enhancing product quality and business performance: the case study of manufacturing companies in Malaysia. International Journal of Quality \& Reliability Management, 29 (1), pp. 92-121.

Chan \& Sim (2011). Can Malaysian firms improve organizational/innovation performance via SCM?, Industrial Management \& Data Systems, 111 (3), pp. 410-431.

Kortana, T. (2015). An Innovative Management Model to Enhance Competitive Potential for Entrepreneurs in Bangkok Thailand. Actual Economy: Local solutions for global challenges (Conference Proceedings).

Garrigos-Simon \& Marques (2004). Carrying capacity in the tourism industry: a case study of Hengistbury Head. Tourism Management, 25 (2), pp. 275-283.

Kennerley \& Neely (2002). The Performance Prism: The Scorecard for Measuring and Managing Business Success. Prentice Hall International, 385 p.

Eldin, S. (2009). Critical success factors for TQM implementation and their impact on performance of SMEs, International Journal of Productivity and Performance Management, 58 (3), pp. 215237.

Tsai \& Lin (2007). Effects of culture conditions on the mycelial growth and bioactive metabolite production in submerged culture of Cordyceps militaris. Biochemical Engineering Journal, 3, pp. 193-201.

Paper submitted

Paper accepted for publishing

Paper published online
12 March 2018

06 April 2018

15 June 2018 